\title{
ANALISIS FAKTOR-FAKTOR YANG MEMPENGARUHI KERUSAKAN BAN PADA UNIT DUMP TRUCK DI PT X
}

\author{
1) Muhammad Ramadhan Anshori, Aqli Mursadin 2), Rudi Siswanto ${ }^{3)}$ \\ 1) 2) 3) Program Studi Teknik Mesin, Fakultas Teknik Universitas Lambung Mangkurat \\ JL. Akhmad Yani Km.36 Banjarbaru, Kalimantan Selatan,70714 \\ Telp. 0511-4772646, Fax 0511-4772646 \\ E-mail : Muhammad.MR800@gmail.com
}

\begin{abstract}
Tire is important component of a Dump Truck. For transporting material from the loading point and fleet to disposal Dump Truck performance is required. Trouble On the tire will interfere the unit performance. Month period data from January to March show the amount of failure to the unit HD785-7 dump truck tire which can indirectly interfere the performance of the unit. Therefore, analysis of two key performance indicator (KPI) that tread utility ratio (TUR) and lifetime must be done to find the factors that cause failure, as well as find out whether there is a relationship between lifetime and TUR against different types of failure that occurred by using logistic regression. From the analysis, it is known that the tire KPI has yet to reach a given target, the main factor of tire performance has yet to reach the target is human error, operator Dump Truck and Excavator by 44\%, from the results of logistic regression analysis of the data for 3 months it is known that the relationship LifeTime and TUR against various types of failure is not significant because Chisq value is greater than the value of 0.05 pr. $(5 \%)$.
\end{abstract}

Keywords: Tires, Keys Performance Indicator (KPI), LifeTime

\section{PENDAHULUAN}

Belakangan ini dunia pertambangan mengalami perkembangan pesat dan banyak sekali perusahaan-perusahaan yang bermunculan, dari banyaknya perusahaan itu salah satunya PT. X.

PT. X memiliki Sejumlah alat berat sebagai alat operasional pertambangan salah satunya adalah Dump Truck, peranan penting Dump Truck adalah sebagai alat vital untuk mengangkut material dari loading point atau fleet ke disposal. Kinerja Dump Truck sangatlah dibutuhkan, jika terjadi trouble pada Ban ini dapat mengganggu kinerja unit.

Ban adalah salah satu bagian / komponen penting dalam suatu sistem pengangkutan tambang khususnya alat angkut. Jam kerja yang tinggi dari alat angkut merupakan tuntutan produksi,menyebabkan kerja dari ban sebagai komponen yang bersinggungan langsung dengan permukaan jalan yang bervariasi semakin berat dan berisiko untuk mengalami kerusakan, Ban berfungsi menahan beban meneruskan fungsi pengereman dan traksi (daya cengkram) ke permukaan jalan/pemindah gaya ,menyerap guncangan dan mengendalikan arah gerak.

Data PT. X periode bulan Januari-Maret memperlihatkan banyaknya kerusakan yang terjadi terhadap Ban Unit dump truck HD785-7 yang secara tidak langsung dapat mengganggu kinerja unit tersebut.Untuk alasan tersebut di atas maka saya mengambil skripsi ini dengan judul; 
Analisis faktor-faktor yang mempengaruhi kerusakan ban pada unit dump truck HD785-7 DI PT. $\mathrm{X}$

\section{TINJAUAN PUSTAKA}

Ban off road merupakan penggerak akhir dari kendaraan yang bersinggungan langsung dengan jalan, yang tidak rata, kasar, buruk, dan berbatu, serta mempunyai ketahanan terhadap keausan dan irisan yang baik bila dibandingkan dengan jenis ban yang lain [1]. Ban-ban offroad yang akan dibicarakan dalam masalah ini terbatas untuk ban yang bekerja di daerah penambangan.

Adapun fungsi utama dari ban dalam sistem pengangkutan tambang, yaitu

1. Menahan berat suatu kendaraan dan muatan yang bersinggungan dengan permukaan tanah.

2. Mengendalikan jalannya kendaraan saat bergerak maju mundur.

3. Meneruskan tenaga dari mesin sehingga kendaraan dapat berjalan dengan baik.

4. Bersama sistem suspensi menentukan keamanan, kenyamanan dan kemudahan dalam pengendalian kendaraan.

\section{Key Performance Indikator Ban}

Merupakan suatu parameter/indikator untuk mengukur performance/efektifitas dari proses maintenance tyre [1].

Elemen-elemen dari KPI Tyre antara lain :

1. Life Time Tyre

Life time Tyre $=$ Umur tyre (Dari ban baru terpasang dari unit sampai ban tersebut sudah tidak terpakai lagi/scrap). Satuannya Hour (jam) atau dengan Kilometer (KM).

2. Tread Utility Ratio (TUR)

Merupakan perbandingan antara penggunaan tread yang terpakai dengan original tread awal.

TUR $(\%)=($ OTD $-R T D) / O T D$. $2.1[2]$

Dimana :

OTD = Original Tread depth/Tread Awal dari ban baru $(\mathrm{mm})$

RTD $=$ Remain Tread depth/Tread sisa $(\mathrm{mm})$

\section{METODE PENELITIAN}

\section{Bahan dan Alat Penelitian}

Berikut ini bahan dan alat yang digunakan dalam melakukan penelitian, yaitu :

a. Bahan Penelitian

1. Unit Dump Truck HD785-7 di PT.X 
2. Ban Bridgestone, 27.00R49, VMTP, E2A, 2*

b. Alat Penelitian

1. Tread Depth Tool, ini berfungsi untuk mengukur ketebalan tread

2. Laptop

3. Kamera Handphone

\section{Pendekatan Penelitian}

Pendekatan yang diambil adalah dengan mempelajari penyebab-penyebab kerusakan ban yang mungkin terjadi. Ini dilakukan dengan pengamatan terhadap keausan, jam kerja dan kerusakan dengan mempelajari dokumen tentang penyebab kerusakan. Selanjutnya, hubungan antara keausan, jam kerja,kerusakan dan penyebabnya akan dianalisis menggunakan modelmodel statistik, Langkah-langkah penilitian digambar seperti pada diagram alir di bawah.

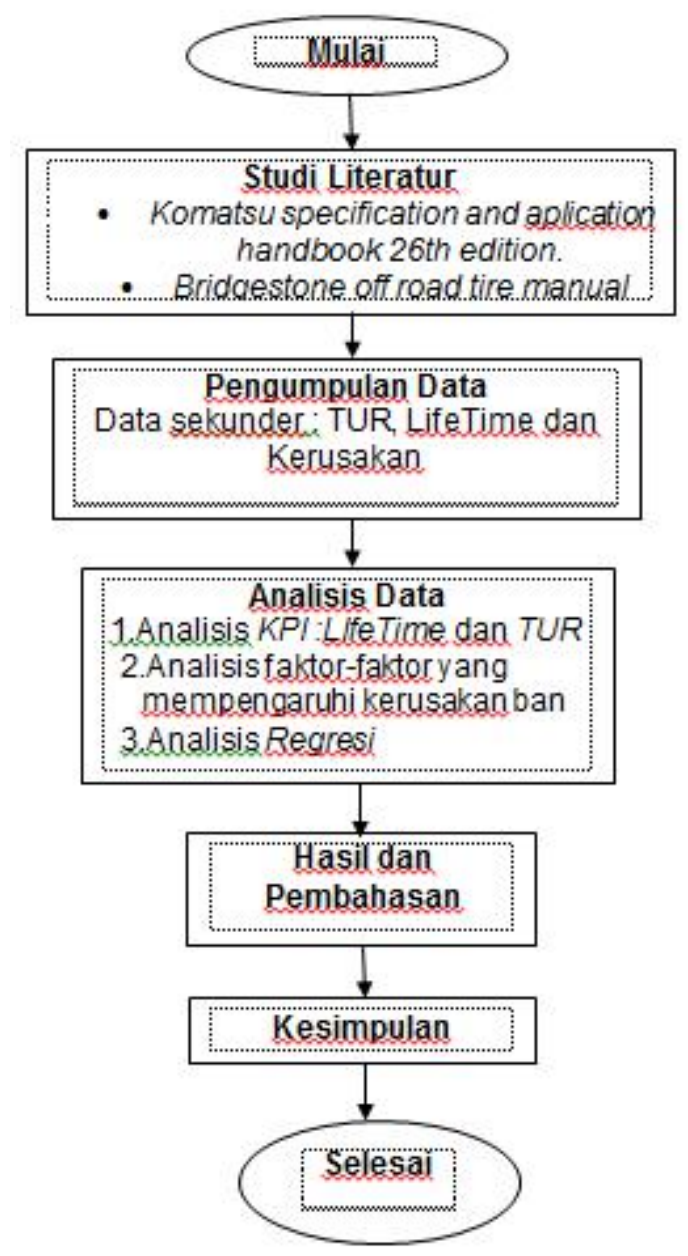

Gambar 1. Diagram Alir Penelitian 


\section{HASIL DAN PEMBAHASAN}

\section{Umur Ban (Lifetime)}

Lifetime merupakan salah satu parameter key performance indicator (KPI), yang menunjukkan umur yang dicapai ban dari ban tersebut digunakan sampai dinyatakan scrab. Dari data lifetime rata-rata scrab ban Januari-Maret 2016, dapat direkapitulasi performa Ban berdasarkan umur rata-rata yang dicapai setiap ban, dan perbedaan (deviasi) pencapaian umur ban aktual dengan target yang diberikan untuk ban ukuran 27.00-49, parameter yang digunakan yaitu,

- Total umur ban (hours machine).

- Jumlah ban yang dinyatakan scrab

- Target umur ban yang diberikan

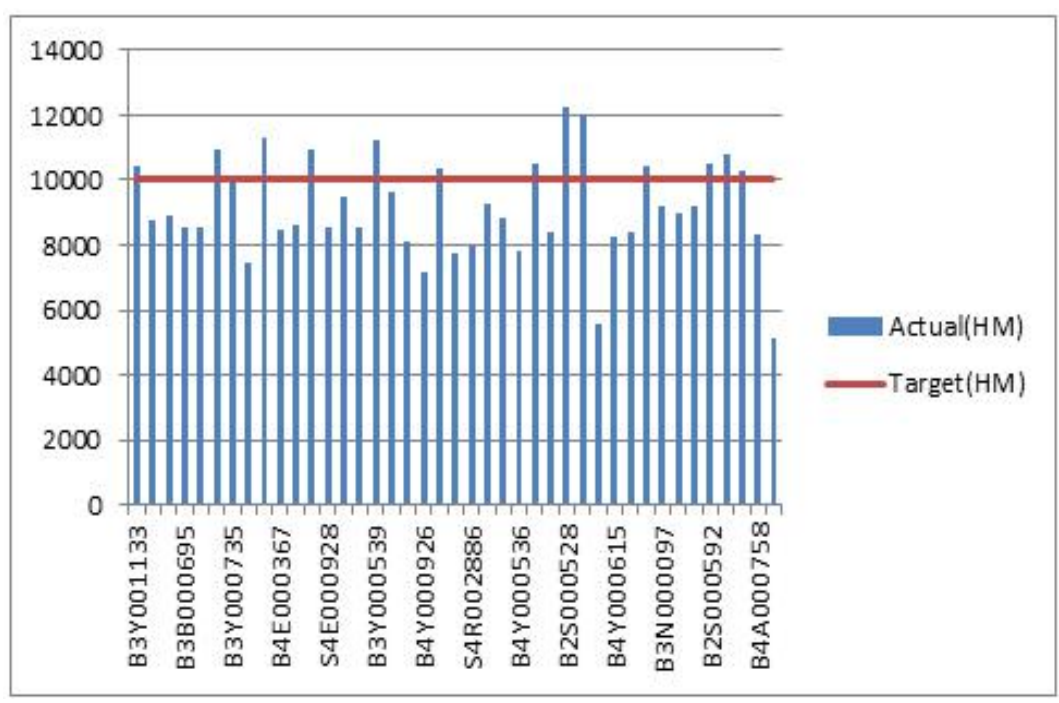

Gambar 2. Umur Ban

Dapat dilihat dari histogram LifeTime Ban diatas, masih terdapat ban yang dinyatakan scrab dengan lifetime di bawah rata-rata, yaitu sebanyak 28 unit ban, dan 13 unit ban yang mencapai target yang diberikan.persebaran data dengan nilai rata-rata sebesar 9166 jam yang diperoleh dari bulan Januari-Maret mengalami deviasi sebesar 834 jam dari target yang diberikan perusahaan sebesar 10000 jam.

\section{Tread Utilization Ratio (TUR)}

Tread Utilization Ratio (TUR) merupakan salah satu parameter key performance indicator (KPI), yang menunjukkan seberap optimum penggunaan kembangan (tread) ban dari ban tersebut digunakan sampai dinyatakan scrab. Dari data Total Tyre Contro (TTC) JanuariMaret 2016 yang terdapat dalam lampiran A, dapat direkapitulasi performa setiap ban 
berdasarkan nilai TUR untuk ban berukuran 27.00-49 dari 41 unit ban, sebagai contoh dapat dilihat pada persamaan dibawah yaitu penghitungan TUR ban dengan serial number B3Y001133 pada bulan januari.

$\operatorname{TUR}(\%)=(73-8.5) / 73=0.88356164$

Tabel 1. Tread Utilizatation Ratio Bulan Januari

\begin{tabular}{|c|c|c|c|c|c|}
\hline QTY & $\begin{array}{c}\text { Serial } \\
\text { Number }\end{array}$ & HM & $\begin{array}{c}\text { Tread Ban } \\
\text { Baru(mm) }\end{array}$ & $\begin{array}{c}\text { Tread } \\
\text { Sisa(mm) }\end{array}$ & TUR(\%) \\
\hline 1 & B3Y001133 & 10432 & 73 & 8.5 & 88.36 \\
\hline 2 & S4E001073 & 8731 & 73 & 32 & 56.16 \\
\hline 3 & S3Y003792 & 8928 & 73 & 30.5 & 58.22 \\
\hline 4 & B3B000695 & 8516 & 73 & 14 & 80.82 \\
\hline 5 & B3B000693 & 8571 & 73 & 32 & 56.16 \\
\hline 6 & B3N000132 & 10910 & 73 & 15.5 & 78.77 \\
\hline 7 & B3Y000735 & 9888 & 73 & 25 & 65.75 \\
\hline 8 & B4A000792 & 7423 & 73 & 32 & 56.16 \\
\hline 9 & B3A000283 & 11305 & 73 & 15 & 79.45 \\
\hline 19 & B4E000367 & 8441 & 73 & 20 & 72.60 \\
\hline 11 & S4E000924 & 8626 & 73 & 25 & 65.75 \\
\hline
\end{tabular}

Tabel 2 Tread Utilizatation Ratio Bulan Februari 


\begin{tabular}{|c|c|c|c|c|c|}
\hline QTY & $\begin{array}{c}\text { Serial } \\
\text { Number }\end{array}$ & HM & $\begin{array}{c}\text { Tread Ban } \\
\text { Baru(mm) }\end{array}$ & $\begin{array}{c}\text { Tread } \\
\text { Sisa(mm) }\end{array}$ & TUR(\%) \\
\hline $\mathbf{1}$ & B3N000125 & 10912 & 73 & 18 & 75.34 \\
\hline $\mathbf{2}$ & S4E000928 & 8564 & 73 & 25 & 65.75 \\
\hline $\mathbf{3}$ & B3Y001105 & 9517 & 73 & 25 & 65.75 \\
\hline $\mathbf{4}$ & B3B000624 & 8521 & 73 & 28 & 61.64 \\
\hline $\mathbf{5}$ & B3Y000539 & 11216 & 73 & 8 & 89.04 \\
\hline $\mathbf{6}$ & B3B000626 & 9664 & 73 & 12 & 83.56 \\
\hline $\mathbf{7}$ & B4E000496 & 8089 & 73 & 22 & 69.86 \\
\hline $\mathbf{8}$ & B4Y000926 & 7161 & 73 & 30 & 58.90 \\
\hline $\mathbf{9}$ & S3Y003789 & 10322 & 73 & 23 & 68.49 \\
\hline $\mathbf{1 0}$ & B4Y000670 & 7753 & 73 & 24 & 67.12 \\
\hline $\mathbf{1 1}$ & S4R002886 & 7995 & 73 & 39 & 46.58 \\
\hline $\mathbf{1 2}$ & S4E000776 & 9298 & 73 & 26 & 64.38 \\
\hline $\mathbf{1 3}$ & S3Y003790 & 8811 & 73 & 21 & 71.23 \\
\hline $\mathbf{1 4}$ & B3N000125 & 10912 & 73 & 18 & 75.34 \\
\hline
\end{tabular}

Tabel. 3 Tread Utilizatation Ratio Bulan Maret

\begin{tabular}{|c|c|c|c|c|c|}
\hline QTY & $\begin{array}{c}\text { Serial } \\
\text { Number }\end{array}$ & HM & $\begin{array}{c}\text { Tread Ban } \\
\text { Baru(mm) }\end{array}$ & $\begin{array}{c}\text { Tread } \\
\text { Sisa(mm) }\end{array}$ & TUR(\%) \\
\hline $\mathbf{1}$ & B4Y000536 & 7792 & 73 & 24 & 67.12 \\
\hline $\mathbf{2}$ & B3B000576 & 10526 & 73 & 20 & 72.60 \\
\hline $\mathbf{3}$ & B4Y000537 & 8371 & 73 & 28 & 61.64 \\
\hline $\mathbf{4}$ & B2S000528 & 12264 & 73 & 20 & 72.60 \\
\hline $\mathbf{5}$ & B3R000871 & 12035 & 73 & 21 & 71.23 \\
\hline $\mathbf{6}$ & B4Y000938 & 5602 & 73 & 45 & 38.36 \\
\hline $\mathbf{7}$ & B4Y000615 & 8282 & 73 & 39 & 46.58 \\
\hline $\mathbf{8}$ & B3A000655 & 8385 & 73 & 30 & 58.90 \\
\hline $\mathbf{9}$ & B3N000123 & 10444 & 73 & 33 & 54.79 \\
\hline $\mathbf{1 0}$ & B3N000097 & 9198 & 73 & 26 & 64.38 \\
\hline $\mathbf{1 1}$ & B3Y001150 & 9000 & 73 & 23 & 68.49 \\
\hline $\mathbf{1 2}$ & B3B000696 & 9206 & 73 & 18 & 75.34 \\
\hline $\mathbf{1 3}$ & B2S000592 & 10532 & 73 & 13.5 & 81.51 \\
\hline $\mathbf{1 4}$ & B3Y001122 & 10795 & 73 & 21 & 71.23 \\
\hline $\mathbf{1 5}$ & B3A000652 & 10272 & 73 & 10 & 86.30 \\
\hline $\mathbf{1 6}$ & B4A000758 & 8348 & 73 & 30 & 58.90 \\
\hline $\mathbf{1 7}$ & S4N002366 & 5165 & 73 & 52 & 28.77 \\
\hline
\end{tabular}

Dari data di atas, dapat dilihat bahwa nilai TUR rata-rata yaitu $66,89 \%$ melebihi nilai standar dimana standar TUR adalah 60\%, dengan 24 ban melebihi dari nilai TUR standart, 13 ban telah mencapai LifeTime yangdiharapkan dan hanya 4 ban yang masih belum melebihi batas TUR. 


\section{Kerusakanz Ban Januai-Maret 2016}

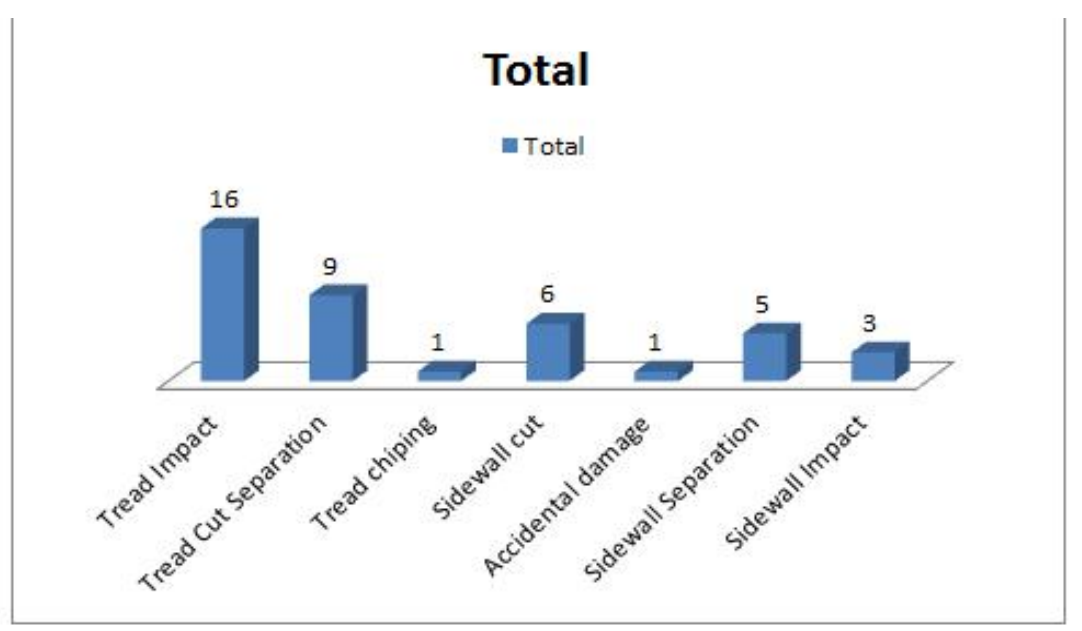

Gambar 3. Kerusakan Ban Januari-Maret 2016

Pada gambar dapat diketahui periode bulan januari-Maret 2016 kerusakan terbanyak yaitu tread impact sebanyak 16 ban. Tread cut separation sebanyak 9 ban, Sidewall Cut 6 ban, Sidewall Separation 5 ban, Sidewall impact 3 ban, Tread Chipping dan Accidental Damage masing-masing 1 ban.

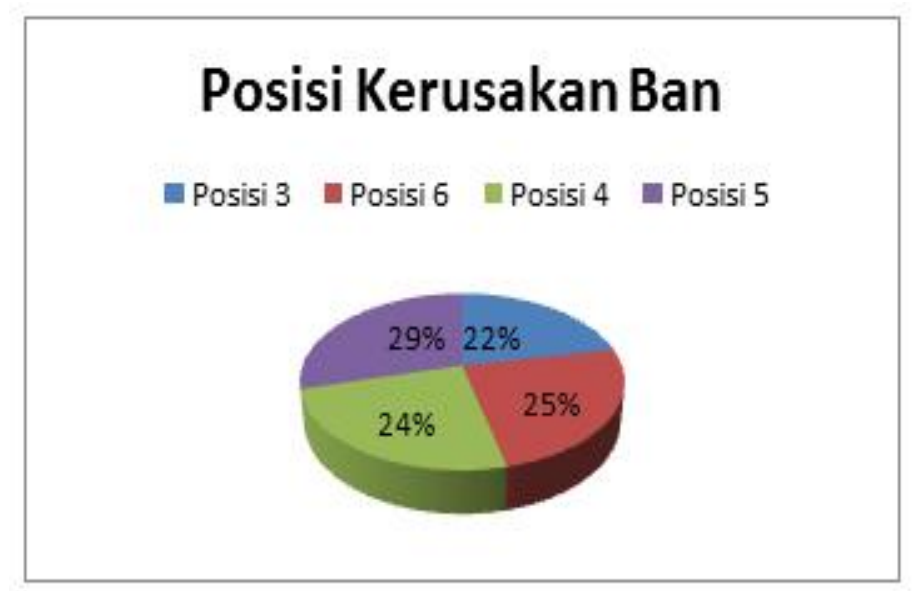

Gambar 4. Posisi Kerusakan Ban

Berdasarkan data total tyre control yang ada, maka dapat direkapitulasi posisi kerusakan ban periode Januari-Maret seperti gambar diatas dimana kerusakan $100 \%$ terjadi pada bagian belakang unit Dump Truck HD785-7.

Tabel 4. Faktor-Faktor Penyebab Kerusakan Ban 


\begin{tabular}{|c|l|c|}
\hline Kode & Jenis Kerusakan & Total Kejadian \\
\hline A & Tread Impact & 16 Ban \\
\hline B & Tread Cut Separation & 9 Ban \\
\hline C & Tread chiping & 1 ban \\
\hline D & Sidewall cut & 6 Ban \\
\hline E & Accidental damage & 1 Ban \\
\hline F & Sidewall Separation & 5Ban \\
\hline G & Sidewall Impact & 3 Ban \\
\hline Total & & 41 Ban \\
& & \\
\hline
\end{tabular}

Berdasarkan pembahasan mengenai kerusakan Ban yang terjadi pada periode JanuariMaret maka akan dibahas mengenai faktor-faktor penyebab kerusakan dengan menggunakan teori-teori yang ada dan mencari penyebab pada masing-masing jenis kerusakan, untuk faktorfaktor yang mempengaruhi kerusakan Ban dapat dilihat pada Tabel dibawah.

Tabel 5. Faktor-faktor Kerusakan Ban

\begin{tabular}{|c|c|c|c|c|c|c|c|}
\hline \multirow{2}{*}{$\begin{array}{c}\text { Faktor-Faktor yang } \\
\text { mempengaruhi kerusakan } \\
\text { Ban }\end{array}$} & \multicolumn{7}{|c|}{ Kerusakan } \\
\hline & A & B & C & D & $\mathbf{E}$ & $\mathbf{F}$ & $\mathbf{G}$ \\
\hline Benturan keras & $\sqrt{ }$ & - & - & - & - & - & $\sqrt{ }$ \\
\hline Over pressure & $\sqrt{ }$ & - & - & - & - & - & - \\
\hline Low pressure & $\sqrt{ }$ & $\sqrt{ }$ & - & - & - & $\sqrt{ }$ & - \\
\hline Kondisi jalan yang buruk & $\sqrt{ }$ & $\sqrt{ }$ & $\sqrt{ }$ & $\sqrt{ }$ & - & $\sqrt{ }$ & - \\
\hline Kesalahan pengoprasian & $\sqrt{ }$ & - & $\sqrt{ }$ & - & $\sqrt{ }$ & - & $\sqrt{ }$ \\
\hline Kesalahan pemasangan & - & - & - & - & - & - & - \\
\hline Berlebihan muatan & - & $\sqrt{ }$ & - & - & - & $\sqrt{ }$ & - \\
\hline Over speed & - & $\sqrt{ }$ & - & - & - & $\sqrt{ }$ & - \\
\hline Kesalahan aplikasi/pemakaian & - & - & $\sqrt{ }$ & - & - & - & - \\
\hline
\end{tabular}


Pada tabel dapat dilihat faktor-faktor penyebab kerusakan untuk masing-masing jenis kerusakan yaitu :

a. Tread Impact dapat diakibatkan oleh faktor Benturan keras, over pressure/low pressure, kondisi jalan yang buruk dan kesalahan pengoprasian.

b. Tread Cut separation dapat diakibatkan oleh faktor Low pressure pada Ban, kondisi jalan yang buruk, berlebihan muatan dan over speed.

c. Tread chiping / Chunking dapat diakibatkan oleh faktor kondisi jalan yang buruk, kesalahan pengoprasian dan kesalahan aplikasi / pemakain.

d. Sidewall Cut dapat diakibatkan oleh faktor kondisi jalan yang buruk.

e. Accidental Damage dapat diakibatkan oleh faktor kesalahan pengoprasian.

f. Sidewall Separation dapat diakibatkan oleh faktor low pressure, kondisi jalan yang buruk,berlebihan muatan dan over speed

g. Sidewall Impact dapat diakibat oleh faktor benturan keras dan kondisi jalan yang buruk.

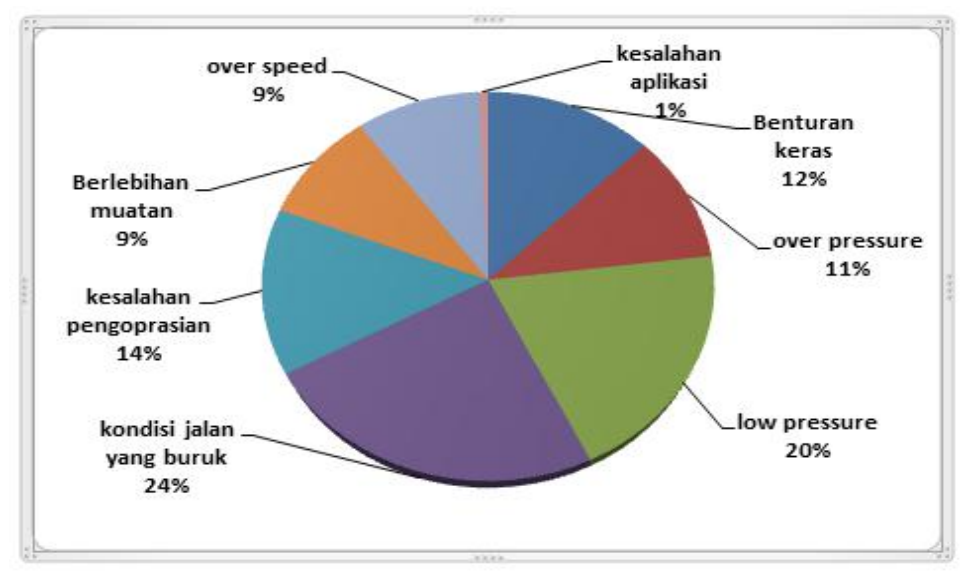

Gambar 5. Faktor-faktor Penyebab Kerusakan

Pada gambar diatas dapat dilihat bahwa kondisi jalan yang buruk berpengaruh terhadap kerusakan ban periode Januari-Maret di PT. X dengan persentase 24\%, low pressure 20\%, kesalahan pengoprasian $14 \%$, benturan keras $12 \%$, over pressure $11 \%$, berlebihan muatan $9 \%$, over speed $9 \%$ dan kesalahan aplikasi $1 \%$.

Jadi dapat disimpulkan bahwa penyebab kerusakan Ban dipengaruhi oleh kondisi jalan sebesar 24\%, kurang baiknya manajemen perawatan Ban 32\% dan faktor terbesar adalah human error operator Dump Truck dan Excavator sebesar 44\%.

\section{Model Regresi Logistic}

Lifetime dan TUR digunakan untuk mengetahui hubungan terhadap masing-masing jenis kerusakan yang terjadi pada Ban. Langkah pertama yang harus dilakukan adalah 
mengklasifikasi life time dan TUR menjadi 3 class dengan tingkatan terndah, sedang dan tinggi menggunakan metode class interval seperti terlihat pada Tabel dibawah.

Tabel 6. Model Regresi Logistic

\begin{tabular}{|c|c|c|c|c|c|c|}
\hline \multirow[t]{2}{*}{ Kerusakan } & \multicolumn{3}{|c|}{ Lifetime } & \multicolumn{3}{|c|}{ TUR } \\
\hline & Rendah & Sedang & Tinggi & Rendah & Sedang & Tinggi \\
\hline $\mathrm{A}$ & $\begin{array}{l}5602- \\
7746\end{array}$ & $\begin{array}{l}7747- \\
9889\end{array}$ & $\begin{array}{l}9890- \\
12035\end{array}$ & $38-54 \%$ & $55-70 \%$ & $71-88 \%$ \\
\hline B & $\begin{array}{l}7792- \\
8963\end{array}$ & $\begin{array}{l}8964- \\
10134\end{array}$ & $\begin{array}{l}10134- \\
11305\end{array}$ & $58-68 \%$ & $69-78 \%$ & $79-89 \%$ \\
\hline $\mathrm{D}$ & $\begin{array}{l}5165- \\
7041\end{array}$ & $\begin{array}{l}7042- \\
8917\end{array}$ & $\begin{array}{l}8918- \\
10795\end{array}$ & $29-43 \%$ & $44-57 \%$ & $58-71 \%$ \\
\hline $\mathrm{F}$ & $\begin{array}{l}7955- \\
8814\end{array}$ & $\begin{array}{l}8815- \\
9672\end{array}$ & $\begin{array}{l}9673- \\
10532\end{array}$ & $47-58 \%$ & $59-70 \%$ & $71-82 \%$ \\
\hline $\mathrm{G}$ & $\begin{array}{l}8089- \\
9480\end{array}$ & $\begin{array}{l}9481- \\
10872\end{array}$ & $\begin{array}{l}10873- \\
12264\end{array}$ & $47-55 \%$ & $56-64 \%$ & $65-73 \%$ \\
\hline
\end{tabular}

Setelah didapatkan classifikasi Lifetime dan TUR dapat dibuat tabel untuk melakukan analisis regresi Lifetime dan TUR terhadap Jenis-jenis kerusakan Ban seperti terlihat pada Lampiran B.setelah dilakukan analisis didapatkan model regresi pada persamaan dibawah.

$$
\begin{aligned}
& \frac{\pi_{i}}{\pi_{B}}=e^{\beta_{i 0}+\beta_{i 1} X_{i 1}+\beta_{i 2} X_{i 2}+\beta_{i 3} X_{i 3}+\beta_{i 4} X_{i 4}} \\
& \text { Dimana: } \\
& X_{i 1}=\left\{\begin{array}{l}
1 \rightarrow \text { untuk Lifetime } 2 \\
0 \rightarrow \text { untuk selain itu }
\end{array}\right. \\
& X_{i 2}=\left\{\begin{array}{c}
1 \rightarrow \text { untuk Lifetime } 3 \\
0 \rightarrow \text { untuk selain itu }
\end{array}\right. \\
& X_{i 3}=\left\{\begin{array}{c}
1 \rightarrow \text { untuk TUR } 2 \\
0 \rightarrow \text { untuk selain itu }
\end{array}\right. \\
& X_{i 4}=\left\{\begin{array}{c}
1 \rightarrow \text { untuk TUR } 3 \\
0 \rightarrow \text { untuk selain itu }
\end{array}\right.
\end{aligned}
$$

\section{Hasil Regresi Kerusakan B}

Tabel 7. Hasil Regresi Kerusakan B 


\begin{tabular}{|l|c|r|c|}
\hline & \multicolumn{1}{|c|}{ coef } & \multicolumn{1}{l|}{ OR } & Pr > ChiSq \\
\hline (Intercept) & 1.2744722 & 3.57681314 & 0.16290311 \\
\hline umur 2 & -0.8939915 & 0.40901989 & 0.49314957 \\
\hline umur 3 & 0.7762317 & 2.17326738 & 0.58063578 \\
\hline tur2 & -2.3383179 & 0.0964898 & 0.05838316 \\
\hline tur 3 & -2.4133758 & 0.08951261 & 0.12252591 \\
\hline
\end{tabular}

Pada Tabel diatas diketahui bahwa hubungan LifeTime dan TUR terhadap kerusakan jenis B tidak signifikan dikarenakan nilai Chisq lebih besar dari nilai pr 0,05.(5\%) Dilihat dari hasil odds ratio diketahui juga bahwa semakin besar LifeTime (umur3) semakin besar peluang Ban untuk mengalami jenis kerusakan B, dan semakin besar nilai TUR(tur3) mempunyai peluang yang lebih kecil untuk mengalami jenis kerusakan B, model regresi Kerusakan B dapat dituliskan sebagai berikut:

\section{Hasil Regresi Kerusakan D}

Tabel 8. Regresi Kerusakan D

\begin{tabular}{|l|c|c|c|}
\hline & coef & \multicolumn{1}{l|}{ OR } & Pr > ChiSq \\
\hline (Intercept) & 0.212015 & 1.2361664 & 0.8440092 \\
\hline umur 2 & -0.6693355 & 0.5120487 & 0.7032608 \\
\hline umur 3 & -1.4141334 & 0.2431362 & 0.4696674 \\
\hline tur2 & -2.2345374 & 0.1070416 & 0.2072421 \\
\hline tur 3 & 0.5515116 & 1.735875 & 0.766892 \\
\hline
\end{tabular}

Pada table diatas diketahui bahwa hubungan LifeTime dan TUR terhadap kerusakan jenis D tidak signifikan dikarenakan nilai Chisq lebih besar dari nilai pr 0,05.(5\%) Dilihat dari hasil odds ratio diketahui juga bahwa semakin besar LifeTime (umur3) semakin kecil peluang Ban untuk mengalami jenis kerusakan D, dan semakin besar nilai TUR(tur3) mempunyai peluang yang lebih besar untuk mengalami jenis kerusakan D, model regresi Kerusakan D dapat dituliskan sebagai berikut: 


\subsection{Hasil Regresi Kerusakan F}

Tabel 9. Regresi Kerusakan F

\begin{tabular}{|l|l|r|r|}
\hline & \multicolumn{1}{|l|}{ coef } & \multicolumn{1}{l|}{ OR } & \multicolumn{1}{l|}{ Pr $>$ ChiSq } \\
\hline (Intercept) & 0.2515346 & 1.2859974 & 0.818893 \\
\hline umur 2 & -1.3468429 & 0.26006 & 0.262204 \\
\hline umur 3 & -1.1558034 & 0.3148045 & 0.4309295 \\
\hline tur2 & -0.3383323 & 0.7129584 & 0.7967503 \\
\hline tur 3 & -0.5123961 & 0.5990585 & 0.7729099 \\
\hline
\end{tabular}

Pada tabel diatas diketahui bahwa hubungan LifeTime dan TUR terhadap kerusakan jenis F tidak signifikan dikarenakan nilai Chisq lebih besar dari nilai pr 0,05.(5\%) Dilihat dari hasil odds ratio diketahui juga bahwa semakin besar LifeTime (umur3) semakin Besar peluang Ban untuk mengalami jenis kerusakan F, dan semakin besar nilai TUR(tur3) mempunyai peluang yang lebih kecil untuk mengalami jenis kerusakan F, model regresi Kerusakan F dapat dituliskan sebagai berikut:

\section{Hasil Regresi Kerusakan G}

Tabel 10. Regresi Kerusakan G

\begin{tabular}{|l|l|l|l|}
\hline & coef & OR & Pr > ChiSq \\
\hline (Intercept) & 0.3179419 & 1.37429643 & 0.78151453 \\
\hline umur 2 & -3.7692187 & 0.02307008 & 0.06895182 \\
\hline umur 3 & -3.1730733 & 0.04187471 & 0.11453723 \\
\hline tur2 & -1.9418835 & 0.14343353 & 0.27982527 \\
\hline tur 3 & 1.7051855 & 5.50240625 & 0.43373479 \\
\hline
\end{tabular}

Pada tabel diatas diketahui bahwa hubungan LifeTime dan TUR terhadap kerusakan jenis G tidak signifikan dikarenakan nilai Chisq lebih besar dari nilai pr 0,05.(5\%) Dilihat dari hasil odds ratio diketahui juga bahwa semakin besar LifeTime (umur3) semakin Besar peluang Ban untuk mengalami jenis kerusakan G, dan semakin besar nilai TUR(tur3) mempunyai peluang yang lebih besar untuk mengalami jenis kerusakan G, model regresi Kerusakan G dapat dituliskan sebagai berikut: 


\section{KESIMPULAN}

1. Kinerja Ban periode Januari-Maret tidak mencapai target yang diberikan karena nilai ratarata lifetime sebesar 9.166 jam dengan deviasi sebesar 834 jam dari target 10.000 jam, dan nilai rata-rata TUR $66,8 \%$ melebihi $6.8 \%$ dari nilai batas TUR maksimum $60 \%$.

2. Faktor-faktor penyebab kerusakan Ban HD785-7 dipengaruhi oleh kondisi jalan sebesar $24 \%$, kurang baiknya manajemen perawatan Ban 32\% dan faktor terbesar adalah human error operator Dump Truck dan Excavator sebesar 44\%.

3. Dari hasil analisis regresi logistic terhadap data selama 3 bulan diketahui bahwa hubungan LifeTime dan TUR terhadap berbagai jenis kerusakan tidak signifikan dikarenakan nilai Chisq lebih besar dari nilai pr 0,05.(5\%).

\section{REFERENSI}

1. David Adetya Zuarsa,, 2015, Evaluasi Kinerja Ban Dump Truck Pada Pengangkutan Di Tambang Lempung-Pasiran PT.INDOCEMENT TUNGGAL PRAKARSA TBK

2. Agresti, A. 2002. Categorical data analysis $2^{\text {nd }}$ Ed:Hoboken, N.J.:John Wiley \& Sons, Inc

3. Agus Sunarto, 2013, Analisis cacat produk ban volkanisir jenis trak dan bus pada CV.Sigma Jaya Surakarta 